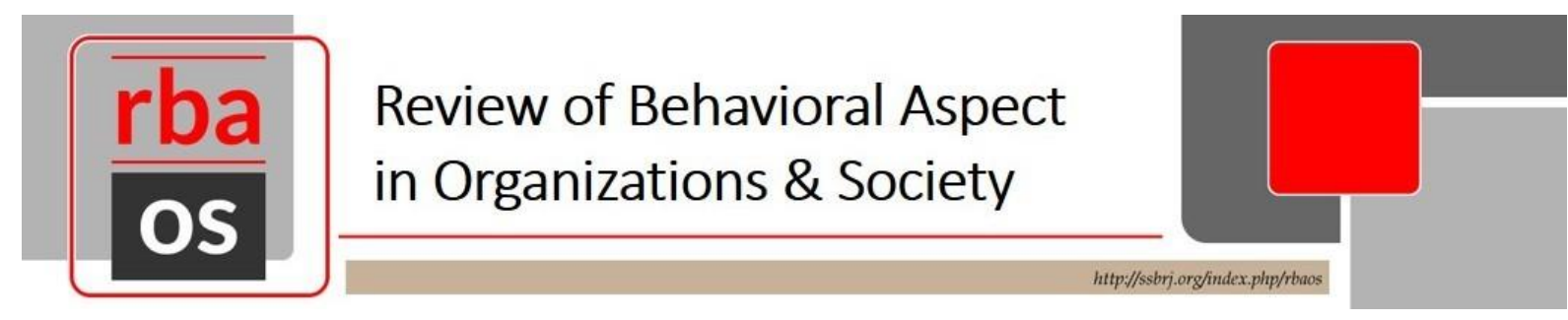

\title{
FALLING DOWN THE KINGDOM: CULTURE AND BEHAVIOR ON FAMILY BUSINESS SUCCESSION
}

\author{
Susminingsih, IAIN Pekalongan, Indonesia \\ Kusuma Chandra Kirana, UST Yogyakarta, Indonesia \\ Sri Hermuningsih, UST Yogyakarta, Indonesia
}

\begin{abstract}
This paper aims to analyze the intersection between culture, behavior, and family in determining the new leader of family business. Organizationally, the culture of family has a significant role in the founder's willingness to hand over his business to someone who is undoubtedly considered the best. This paper uses a qualitative approach where the appropriate theoretical foundation is applied to explain the succession of family business. However, observation method is used in order to obtain the facts of family business succession of batik industry in Pekalongan City, Indonesia. Meanwhile, the sociology and psychology approach used to analyze these facts; therefore, the succession process can be explained correctly. This paper provides several important results of family business succession in Pekalongan City, Indonesia. The succession tends to be carried out in several stages; therefore, the process runs smoothly, i.e., the successor improves his/her ability in managing the business, and then its predecessor reduces their responsibility. Further, the succession process consists of two models, namely planned and unplanned models, where they have their strengths and weakness. We believe some factors influence the succession process, such as motivation, commitment, and dependence of predecessor and successor.
\end{abstract}

Keywords: culture, behavior, family business, succession 


\section{Introduction}

As research on family firms and work on theories of family firms has progressed, the concept of "familiness" as a multidimensional continuum has gained credence (Chrisman, J. J., Chua, et al., 2012). Familiness as ranging from synergistic to constrictive. Synergistic familiness would have beneficial effects on firm performance by entrepreneurial orientation (Zellweger, et al., 2012), but constrictive familiness would have negative effects on firm performance (von Schlippe, and Frank, 2013; Filser, et al., 2013).

Understanding the family business is by understanding it as a dynamic system-based process (Peiper \& Klein, 2007; Bennedsen, et al., 2015). The family roles, communication, such goals, commitment, and strategy depend on the personality of each member in the family (Kotlar and De Massis, 2013; Marler, et al., 2017). The role of culture on business organizations has been widely discussed. It is commonly known that culture and behavior have both advantages and disadvantages in the succession of family business. There is uncertainty about the successors whether they come from inside or outside the family.

Nonetheless, nepotism often becomes a pattern of succession (Checkly, 2010). The values believed by the predecessor and successor determine how the parties behave to carry out their respective roles and functions. Cultural suitability is usually an important reason for a leadership transition by involving successors. Therefore the behavior of transfer of power to a successor will always be a crucial issue for the family firms. Succession in family firms is the subject which much studied by the experts (Long \& Chrisman, 2014; Gilding, et al. 2015; Bracci, and Vagnoni, 2011; Tirdasari, and Dhewanto, 2012; Bennedsen, et al. 2015). They claim that transfer generation of family firms is not easy; it takes time and proper succession planning series in order to proceed with the family firms to the next generation (Higginson, 2010).

Family is a very strong and fundamental social institution. Families who have valuable values for the company throughout their history have a significant role in the pattern of succession that occurs in the family business. The study of organizational culture becomes a necessity in understanding how the family business as a set of individuals carries out their business activities. Therefore, a family is a key to capital accumulation of family companies where each individual has a specific form and role. Transition inter-generations in the family business make a unique succession (Zellweger et.al, 2012; Palliam et.al, 2011).

Since the 1960s, many studies have discussed succession, especially in management studies. Succession is an attempt to turn business management to the next generation, whether it is planned or not (Gilding, et al., 2015). Therefore, the success of a company also depends on the succession process. Successor's commitment as a form of responsibility for developing family business after the transition process becomes an important value for the company - the values developed by the family influence ongoing business management. Due to intangible resources in the family business organization, the description of the family business becomes very complex and dynamic.

Meanwhile, both actions and decisions of the current leader affect the process of succession (Checkly, 2010). Furthermore, Berkel (2007) reports that succession in a family business is an important event, which may change the direction of the business. It is believed to bring business success when the new leader cannot only maintain but also improve the competitiveness of the family business. This success is likely to continue until a transition is unavoidable, where the succession process is carried out to turn business management to future generations (Berkel, 2007). 
Therefore, the direction of family business can be determined even when the preparation process of succession is planned. That's why the process of succession gains a great deal of attention in the family business.

\section{Theoretical Review}

Family factors influenced the sustainability of family firms. Succession is the key to sustainability and the success of the family firm's performance in the future. Some studies also show that succession influences firm resilience in the future (Chrisman, 2011). It is not surprising when the issues of succession have become the most widely studied topics in the literature research of the family business (Decker et al., 2016). Many researchers found that both of the family power and family culture have a positive influence on the ambidextrous orientation in family firms and that higher levels of ambidextrous orientation lead to better economic performance (Stubner, et al., 2012; Erdem and Baser, 2010; Zachary, R.K, 2011). Family firms suffer less from agency costs because ownership and management are in the hands of the family, and agents and shareholders have the same goals to manage the business (Park and Shin, 2016). Family business succession is controlled by many factors that drive resistance and factors that reduce business resistance, at the individual level, interpersonal group level, organizational level, environmental level. The model of resistance to succession in family business occurs depending on the strength of the factors that arise in business organizations that they shared between them as long as their business relations.

The connection between promoting and reducing resistance can be understood in figure 1 .

Factors Promoting Resistance

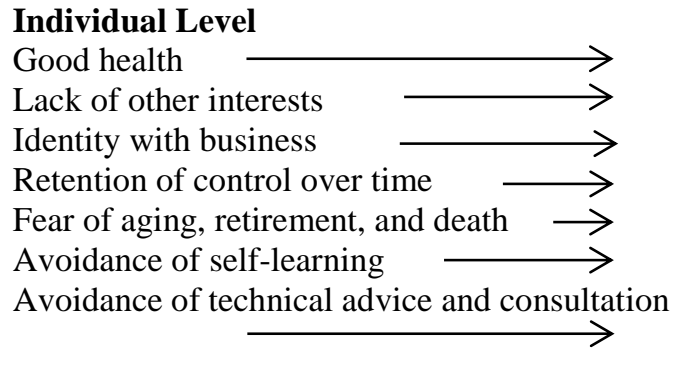

Interpersonal Group Level

Lack of open communication Minimal trust

Heir(s) are or appear disinterested, incapable, inexperienced, or inappropriate Minimal training Power imbalances Family conflicts or issues permeate the business Nuclear and extended family members as potential heirs

Culture threatens organizational development

Stability of organizational growth

\section{Factors Reducing Resistance}

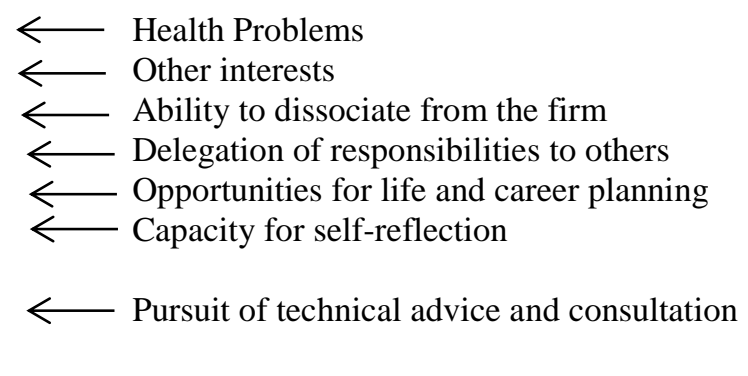

\footnotetext{
$\leftarrow$ Honest, informed communication is encouraged $\leftarrow$ High level of trust

$\leftarrow$ Heir(s) are actively and capably involved in the business

$\leftarrow$ Mentoring is encouraged and practiced

$\leftarrow$ Shared power

$\leftarrow$ Family dynamics are separated from business issues

$\leftarrow$ One child as potential heir
}

Organizational Level

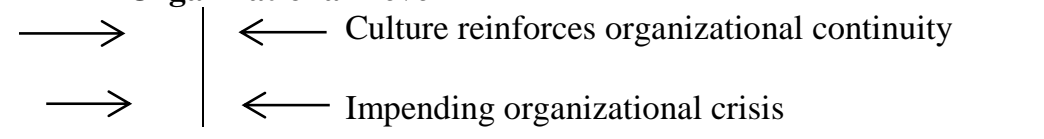




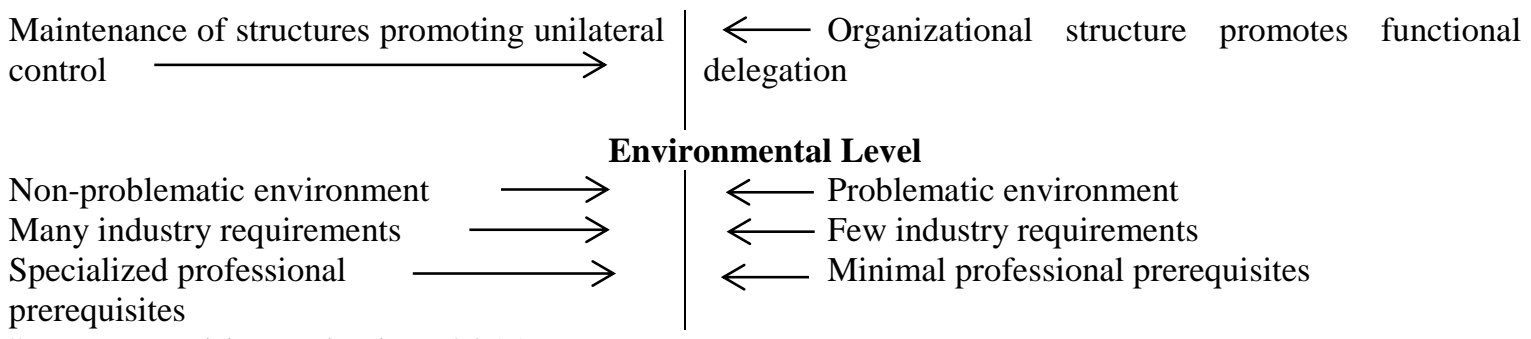

Source: Lachlan Whatley, 2011

Figure 1: A Model of Resistance to Succession in the Family Business

General speaking, there are two types of succession that are usually carried out by family businesses, namely planned and unplanned types. Analytically, these patterns have different effects especially in human resources, culture, business orientation, managerial abilities, and talent in dealing with business problems that constantly change according to market orientation. Each type of succession becomes a behavior in the family business so that business continuity also depends on the pattern used in the succession process. In a planned succession type, the successor has better preparation to become a new leader both individually and socially because of getting support from other family members. They do not mind to provide full support because they also have a strategic role in business management. In contrast to unplanned patterns, successors do not fully have such complex managerial readiness. Their abilities also tend to be simple in running a business because it is not to develop business levels. The following is a description of the pattern of succession planning based on the planned behavior:

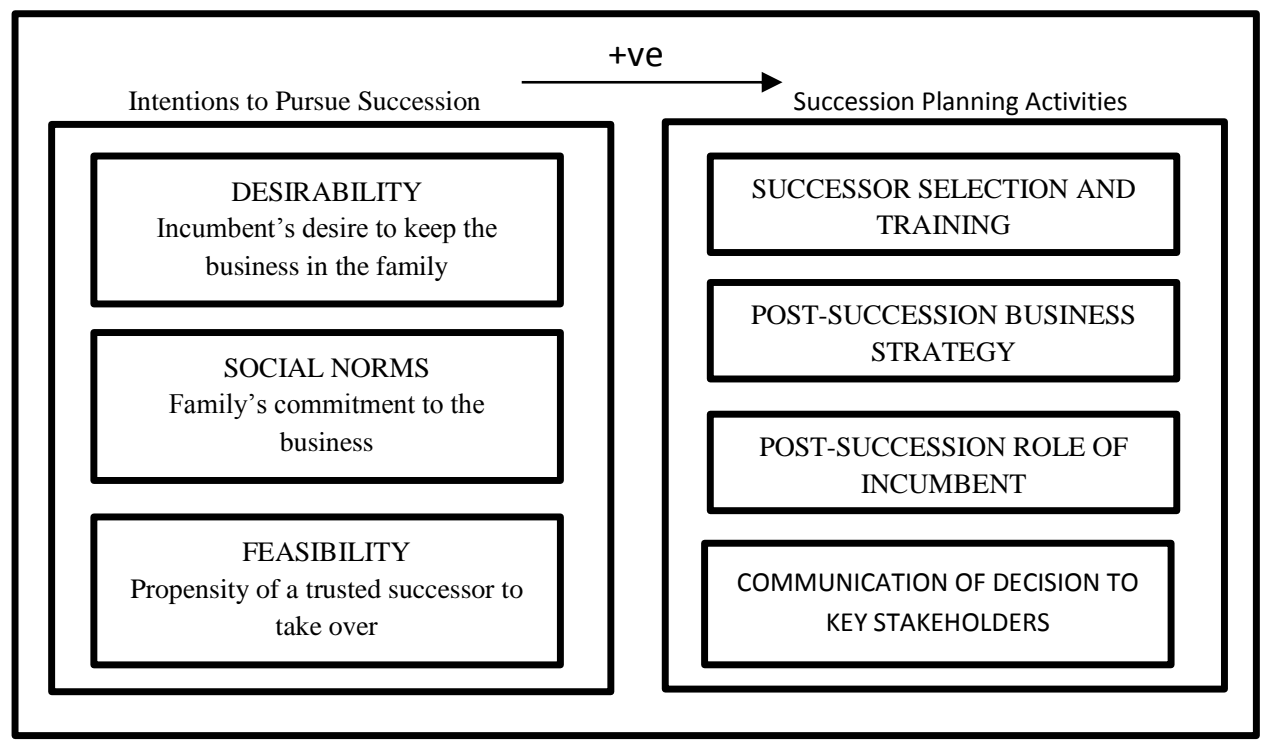

Source: Sharma et.al (2003)

Figure 2: Planned Behavior Model of How Family Firm Characteristics Influence Engagement in Succession-Planning Activities

The purpose of the family is to establish a business based on family values believed by its members as a shared value to produce family culture. The family builds the organization's culture as well as 
build their trust for each other. The family institution conducts a process of socialization of values and norms to direct the behavior of family members to manage the organization much better because of its role as a very strategic socialization agent. It's easy to understand because family institutions have unlimited time in managing family members' behavior, starting from childhood to adulthood, even to the next generation (Vallejo, 2011). The most responsible for the business succession is the founder of the company or the first generation, some other researchers focus more on the successor experience or the next generation, and the rest is both parties which is the relationship between succession and parents. Incumbent decisions as the founder have a strong influence on the next leadership (Boyd, et al., 2014). Therefore, a set of proper planning is needed to accelerate the succession process (Rasyid and Sobirin, 2013).

Family members' involvement in the family business has advantages and disadvantages at the same time. There are some positive impacts of their involvement, where the most important is in management matters (Molly, et al., 2010). Also, both warm relationships and personal suitability positively influence family business. Those situations open up opportunities and a synergistic understanding, especially in business decision making. In this case, the roles of normative, cognitive and affective structures take place simultaneously. Business behavior is carried out sociologically. Internal adjustment capabilities turn into capital when family business faces challenges (Kellermen, Eddleston, Sarathy \& Murhpy, 2010).

Conversely, the emotional connection of family members may bring weakness to the business management system. Overlapping interests between business and family allow successors to behave unfairly in making business decisions. The culture of protecting each other, caring, trusts that initially ties the members of family but in the end they may trap the leaders in making decisions that mix business and personal matters. A paradoxical relationship, which is full of suspicion, elicits distrust, lack of responsibility, and tends to be dismissive. Business as an institution is no longer able to be a catalyst that delivers shared values in the family. The distortion of sustainable business goals by self-interest leads to business failures and even bankruptcy, due to unprofessional management and violation of business regulations.

The institutional mechanisms in the family business organization show how the transition of family values is normatively passed on to future generations. Parents provide knowledge about how the principle of compassion translates into business action with family members by sharing roles and responsibilities. Thus, the business belongs to the family where all of the family members are entitled to manage the family business. In contrast to the principle of cognition which explains how values are analyzed by parties outside the family.

The limit of the advantages and disadvantages of family business success lies in an indistinct area, which is a behavior to pay attention to the community environment that starts with family members to other family members. It means that beliefs, norms, and values of goodwill determine how the community of the family behaves (Rashid, et.al, 2008). The family environment orientation also causes the family business into the downfall of the already-built business into a giant company. Several dimensions which can be described from the family business which may affect the succession of the family business are as follows. 


\section{Social Entity}

Historically, family businesses that have been developed for generations tend to have very strong capital resources, materially as money capital, raw materials, design, production tools, and employment. A wide network makes family business becomes familiar to the business founders. Trust that has been built by the predecessor becomes an important capital for the new leader in continuing family business. The important thing that must be considered by the successor is to keep the trust as a business foundation.

The family is the smallest unit of society, which is formed by human. Unpredictable and sometimes difficult to guess, making organic relationships in the family is abstract (intangible). The successors' success is determined not only by the physical capabilities, which are represented by the complete facilities. However, the values shared by family members in guiding the way they interact both internally and externally make family business more a social reality. A depth of emotions fosters loyalty and a sense of responsibility in the family.

\section{Unstructured way in obtaining knowledge}

Experiences in marketing, finance, production, employment, and product designing are very helpful in developing the family business, especially in making decisions related to business development to minimize the risk of loss that has been carried out for generations. Generally, the pattern of work in an organization is made by creating a complete work structure. In the family business, a predecessor does not always choose successors according to their experience and knowledge. Generally, based on family structure, the oldest child has the greatest chance of receiving a business management relay.

The existence of existing predecessors leading the previous business organization has an early chance in establishing the vision of the business organization. Successor experience in running a business organization to be able to survive is associated with the courage to take risks. Owners who have double roles, namely as founders and predecessors usually delegate the leadership of the company by not always doing their succession planning to successor. Successors and predecessors who live together tend to work in business using a type of togetherness.

\section{Predecessor and successor characters}

In a family, the predecessor and successor have interacted for a long time. Genetic and social factors make them adjust to each other easily where this adjustment also determines the personal suitability of family members in running a business organization. Personal involvement has a high contribution to the organization. This is because organizations become more effective in achieving the goals of the organization itself. Both people group and people objection become the basic essence of the organization. The people group is defined as a group of people who come together with similar characteristics. Meanwhile, people objection believes that a business organization is established so that the people who get together and the organization get the same goals.

In the family business, two essences experience dynamics. Predecessors and successors are initially in a narrow area, making communication and interaction between them occur dialogically and there has not been a widening of interest from their children and families to the nuclear family of the predecessor. Business continues to grow directly proportional to the development of family and interests. At one point, mixing business and family is no longer ideal because family personal 
is not pure. Even the family knew this problem they always tried to reach the sustainability of their family business. The initial assumption of businesses for family and family for business is not agreed. The purpose of "togetherness" is interpreted as the "similarity" of the desired goals of members and organizations tend to experience "digression", where the successor's interests tend to increase and prioritize. Personal and organizational internal conflicts open opportunities to change the vision and mission of business organizations, which are different from their initial intentions (Kellermanns, et.al, 2004). Then the company grew up or slowed down depending on this result.

Personal changes of successor and predecessor may influence the direction of the organization in the family business. The relationship conflict between family members greatly affects the ability of family business management. The conflict affects the productivity of the family business. However, family cohesiveness also has the opposite risk, precisely when each family member tries to maximize the values of business benefits but they have different decisions and actions with other members, which may threaten the welfare of the family (Kellermanns and Eddleston, 2004). The firm or business is a system that is rational and task-oriented. In simple terms, it is often stated that the firm aims to maximize profits since the profits of the firm can continue and develop their business. If the firm fails to achieve the target as they want, the consequence will happen that the firm should be closed or bankrupted and lose their opportunity to develop. Then, the business is over. Families, on the other hand, is a system that relies on feeling based on heredity or family relationship, whose presence is required to support and meet the needs of (social and emotional) between all members of the family. The family concerns about creating strong communication and commitment to shaping the culture of business organization. This paper points out that culture and behavior succession important role in family business sustainability.

\section{Methodology}

This study uses a descriptive qualitative approach, which is an approach using data in the form of sentences, events, knowledge, or descriptive study projects (Yin, 2009). This study relies on the owner of the batik family business in Pekalongan city to obtain facts about the succession process. The reason for choosing batik industry as a basis to study family firms is its uniqueness. Most, if cannot be said all, the entrepreneur in this industry are the family firms owned by less educated persons and being managed informally following the local cultural values. The characteristics of this business suggest that the business is susceptible to longterm survival, even this business run to the second or third generation. Family business theory, organizational culture, and behavioral succession are used as discussion material to produce appropriate conclusions in this study. The facts of the succession process are analyzed by using both sociology and psychology approaches.

It is important to point out that integrative and interdisciplinary research processes from organizational culture, sociological studies as well as industrial and organizational psychology are needed in family business analysis. This paper analyzes the family business as a cultural entity that develops from time to time and dynamically contributes to business development more attractively. Furthermore, this paper consists of several thematic types of research to build an academic recommendation on the family business.

\section{Discussion}

Types of batik business are spread in several provinces in Indonesia, as listed in Table 1. 
Table 1. Percentage of the Distribution of Hand-drawn Batik Industries in Java Island in 2015-2017

\begin{tabular}{|c|c|c|}
\hline No. & Province & Percentage \\
\hline 1. & East Java & $20 \%$ \\
\hline 2. & Central Java & $30 \%$ \\
\hline 3. & DIY & $15 \%$ \\
\hline 4. & DKI & $8 \%$ \\
\hline 5. & West Java & $21 \%$ \\
\hline 6. & Banten & $6 \%$ \\
\hline 7. & Amount & $100 \%$ \\
\hline
\end{tabular}

Source: Trade, industry and cooperative services, 2010

Table 1. shows that Central Java which Pekalongan City located has the highest percentage (30\%) compared to other provinces. The high percentage of the number of batik industries in Central Java shows that the province is still the center of batik industry led by family system leadership, together as the owner. In the case of Indonesian family firm, 3\% of family businesses that still survive until now was built in 1932 to $1943,2 \%$ built-in 1944-1955, 10\% was built in $1956-1967,24 \%$ was built in 1968-1979, 24\%, was built in 1980-1991 and 37\% were built in 1992-2003 (Kodrat \& Gunawan, 2007). The rate of low succession as shown in the above findings, indicates that succession is very complex and is a challenging process involving not merely the parent and the heir but also many other stakeholders. Indeed, the failure of succession is sometimes caused by the reluctant of a successor to accept the leadership of inherited business (Sharma et.al, 2003; De Massis et.al, 2008). This problem is very dangerous for the sustainability of the business, and many successors did not know it well.

The culture of family business is constructed based on family values. They not only bind but also limit the family's organizational culture slowly and structurally. It is important to note that values represent the most basic level of cultures, which are soft conditions that unconsciously may lead people to good or bad things (Alas, 2009). Culture has enormous power in business management due to its role may determine the direction of business change. In a behavior perspective, the business change needs a new behavior response. Meanwhile, Vallejo (2011) states the successful strategy in the business is determined by the organizational culture whereas Brice and Jones (2008) report that companies are able to gain optimal benefits by using culture properly.

Cultures in family business are inseparable from the values believed by family members. Generally, in family business, there is no separation of individual interest where one's member interest belongs to all family members. For example, parents and their children have a similar interest; a brother's interest becomes other's interest and so on. This is often the beginning of a mixture of business management and family culture where corporate culture is ultimately constructed by family values. Furthermore, the decision-making process in family business is based on a sense of "togetherness" in the family. A sense of having a similar fate encourages them to share their interests to other family members becomes a behavior in family culture that is built and maintained continuously.

Common family characters such as interdependent, faithful, and openness are often expressed in the behavior of family business. Every family member feels they are a part of the business therefore 
they are entitled to the whole family business. However, this interdependent value is essentially less effective for business management. Family business usually tends to be less transparent and it is difficult to develop the business due to a sense of discomfort, lack of responsibility, risk aversion, and handing business matters to other family members.

In some societies, the process of succession is very simple. The main factor that is often considered in determining new leaders is seniority, where the oldest siblings are usually prioritized to become successors. Consequently, business management runs conservatively, which less adaptive to market reactions because they only carry on what has been produced by their predecessors, less innovative so that the business develops slowly and requires a longer time in achieving success (Uhlaner, Kellermans, Eddleston and Hoy, 2012).

Business succession has been widely discussed since the 1960s. Succession or transition of management leadership refers to the effort to transfer management control from one family member to another intentionally (Mussolino, and Calabrò, 2014). Family business management has a different character from non-family companies because it has more complexity and sensitivity of the values that are developed in organizational culture, which causes business progress also faces more complex problems.

Therefore, the change of management has a central position that affects the business family. It may affect positively or negatively on family business depends on the ability of the new leader in organizing business management. Generally, a family business carries out the succession process by involving only family members (internal) while the outsiders are ignored (Checkly 2010). Nepotism patterns are more likely to be chosen because of the appropriateness of value that has already developed long enough in the family, which makes communication and trust easier to adjust.

To understand the succession of the family business, it is very important to understand the system of family business as well as the stakeholders or related parties that build the system. Family businesses have unique features like commitment, shared values, culture, trust, reputation and so on, where they become strategic resources and capabilities that can be beneficial for the long term in business management. Succession issues in family businesses involve many elements, namely family factors, business factors, personal factors of successors and predecessors, and markets. All of these factors lead to a more complex succession process of the family business (Rashid, et.al, 2013). Business risk also adds to the complexity of the problem where the family is the source of both reason and purpose.

Family companies are a combination of strengths and sources of unique values, which are the result of business and company interactions (Krauss et.al. 2011). It's no wonder that family companies have the same characteristics as family characters, namely warmth, togetherness, caring, loving, and protecting. That is why the head of the family or the oldest brother, as a leader of the family business, has the greatest responsibility in controlling the business (Liu, Yang \& Zhang, 2012). Values, norms and value systems influence a family member in behaving with other members in certain ways or actions. Accepted attitudes and actions show a shared value in the family. Family members usually have similar perceptions, i.e., business for families and families for business. The cohesiveness of family value becomes the integrated power as well as the decoder 
for the family business. Values that can build culture may facilitate family institutionalization into business where the culture is a significant determinant of business success. A culture of protection for each family member is part of the success of family business. Due to many people feel obliged to contribute, then family business can grow quickly. The relationship among family members may motivate other members in taking an important role in business management.

Family business management knowledge is generally obtained by self-taught where they study directly from family member by seeing and practicing. It is important to point out that this knowledge is usually passed down from generation to generation. The process of business transition takes place slowly because the preparation process in finding a suitable replacement is done over a long period of time. The basic knowledge of business management does not rely on formal business school, but through family culture. Therefore, family culture creates values of wholeness and concern as shared values, which grows and are received simultaneously (Rashid, et.al, 2008).

By using family characters, both commitment and responsibility are very high. Therefore, they are highly motivated to maintain the family business, which has been established for generations hereditary. This commitment of family values eventually becomes the greatest strength to business ownership (Tapies et.al, 2010). On the contrary, efforts to maintain this business may bring the family business into a stagnant situation or even bankruptcy when there is no significant effort to develop established innovations, where innovation is a decisive part of business development (Krauss, Pohjola and Koponen, 2011; Kellermans, Eddleston, Sarathy and Murphy, 2010). The emotional closeness of family members in this business has equal probability in actuating and destroying business management. Therefore, the founder of family business has a very important role in policymaking because there are so many factors from the internal family members that may destroy family business. Violations, breaking promises, irresponsibility, carelessness that causes disappointment, reluctance, and pity have a very high possibility to reverse family business.

Furthermore, succession or management transition is only interpreted as a technical transition which is not supported by the management development process based on professionalism, innovations, and competitions. It is important to note that there is a huge risk when succession is only seen as a technical transfer of management leadership. These risks may lead to a negative effect on not only business development issues but also social problems among family members. This type of succession carries a big risk on commitment, hard work and the value of company as development issues as well as social issues such as jealousy, distrust and a different sense of responsibility. By considering business development, the meaning of succession needs to be reinterpreted where succession is not only a technical transfer of leadership but also as a planned process, which is the progressive and regressive dynamics of many intangible resources. This dynamics condition greatly affects behavior change in family business organization.

Family contextual dimensions such as environment, population, culture, availability of material supply, and technology play an important role in the continuity of family business. The way of family business deals with business changes is also determined by the behavior of decision-making that previously happened in family organization. In many cases, the way a father educates his children by transferring family values such as altruism, love and maintaining harmony is not always replicated by the children properly. Unfortunately, the powers concentrated on the 
predecessor that are eventually imitated by the successors have more adverse effects on business management. This type of concentration of power varies for every family business. The absolute business authority that is owned by the predecessor is not always the same as the successor's decision. The high dependence of successors and predecessors makes family businesses vulnerable to disunity when both values and culture are no longer in agreement. In other words, this high dependence indicates high tension.

\section{Closing}

This paper concludes that family as a business organization is rather a social reality than a physical reality. The interaction between successor and predecessor has been carried out along with the family growth. The long duration of this interaction is intended to make values that are mutually agreed by family members become a family culture, which has enormous strength and is not easily destroyed. The business principle held by all family members, namely families for business and business for families, makes the family business last for generations. On the contrary, when a member has a different perspective from the organization then there is a possibility of a direction change in the family business management. The direction change need a compromise of understanding each other. Therefore, business commitment in the family business is divided into two things, namely maintaining personal goals or organizational goals.

Furthermore, this paper also analyzes the unstructured way to gain knowledge which has the greatest contribution to the fall of the family business. A work method that is only getting together to make business commitment is less resilient when family business faces challenges both from internal and external families. The absence of succession planning actually weakens the family business organization itself. This is due to the growing values that have high complexity, and family culture is also more dynamic.

\section{References}

Alas, R. (2009). The impact of work-related values on the readiness to change in Estonian organizations. Journal of Business Ethics, 86(2), 113-124.

Berkel, H. G. (2007). Father to son: The mediation of family firm succession conflict (No. 3373). Kölner Wissenschaftsverlag

Bennedsen, M., Fan, J. P., Jian, M., \& Yeh, Y. H. (2015). The family business map: Framework, selective survey, and evidence from Chinese family firm succession. Journal of Corporate Finance, 33, 212-226.

Boyd, B., Botero, I., \& Fediuk, T. (2014). Incumbent decisions about succession transitions in family firms: A conceptual model. International Journal of Financial Studies, 2(4), 335-358.

Bracci, E., \& Vagnoni, E. (2011). Understanding Small Family Business Succession in a Knowledge Management Perspective. IUP Journal of Knowledge Management, 9(1).

Brice, W. D., \& Jones, W. D. (2008). The cultural foundations of family business management: Evidence from Ukraine. Eurasian Journal of Business and Economics, 1(1), 3-26. Checkly, T. (2010). Succession in Small and Family Businesses, research report.

Chrisman, J. J., Chua, J. H., \& Steier, L. P. (2011). Resilience of family firms: An introduction. Entrepreneurship theory and practice, 35(6), 1107-1119.

Chrisman, J. J., Chua, J. H., Pearson, A. W., \& Barnett, T. (2012). Family involvement, family influence, and family-centered non-economic goals in small firms. Entrepreneurship theory and practice, 36(2), 267-293. 
Decker, C., Heinrichs, K., Jaskiewicz, P., \& Rau, S. B. (2016). What do we know about succession in family businesses? Mapping current knowledge and unexplored territory. In The Routledge Companion to Family Business. Oxford, UK: Routledge, 15-44.

Erdem, F., \& Gül Başer, G. (2010). Family and business values of regional family firms: a qualitative research. International Journal of Islamic and Middle Eastern Finance and Management, 3(1), 47-64.

Filser, M., Kraus, S., \& Märk, S. (2013). Psychological aspects of succession in family business management. Management Research Review, 36(3), 256-277.

Gilding, M., Gregory, S., \& Cosson, B. (2015). Motives and outcomes in family business succession planning. Entrepreneurship Theory and Practice, 39(2), 299-312.

Higginson, N. (2010). Preparing the next generation for the family business: relational factors and knowledge transfer in mother-to-daughter succession. Journal of Management and Marketing research, 4(1)1-18.

Kellermanns, F. W., Eddleston, K. A., Sarathy, R., \& Murphy, F. (2012). Innovativeness in family firms: A family influence perspective. Small Business Economics, 38(1), 85-101.

Kodrat, D.S. \& Gunawan, L. (2007). Life Cycle of Indonesian Family Business. Economy Faculty of International Business Management Department Ciputra University.

Kotlar, J., \& De Massis, A. (2013). Goal setting in family firms: Goal diversity, social interactions, and collective commitment to family-centered goals. Entrepreneurship Theory and Practice, 37(6), 1263-1288.

Kraus, S., Pohjola, M., \& Koponen, A. (2012). Innovation in family firms: an empirical analysis linking organizational and managerial innovation to corporate success. Review of Managerial Science, 6(3), 265-286.

Liu, W., Yang, H., \& Zhang, G. (2012). Does family business excel in firm performance? An institution-based view. Asia Pacific Journal of Management, 29(4), 965-987.

Long, R. G., \& Chrisman, J. J. (2014). Management succession in family business (pp. 371-387). Sage Publications: London, UK.

Uhlaner, L. M., Kellermanns, F. W., Eddleston, K. A., \& Hoy, F. (2012). The entrepreneuring family: A new paradigm for family business research.

Marler, L. E., Botero, I. C., \& De Massis, A. V. (2017). Succession-related role transitions in family firms: The impact of proactive personality. Journal of Managerial Issues, 29(1), 57-81.

Molly, V., Laveren, E., \& Deloof, M. (2010). Family business succession and its impact on financial structure and performance. Family Business Review, 23(2), 131-147.

Mussolino, D., \& Calabrò, A. (2014). Paternalistic leadership in family firms: Types and implications for intergenerational succession. Journal of Family Business Strategy, 5(2), 197-210.

Palliam, R., Cader, H. A., \& Chiemeke, C. (2011). Succession issues among family entrepreneurs in countries of the gulf. International Journal of Business Administration, 2(2), 25.

Rashid, A. \& Sobirin, A. (2013). "Abandon The Ship" - Transition and Succession Planning in Family Farming Business: A Case Study in Small Medium Rice Mill Businesses in Kabupaten Lampung Tengah, paper presented in International Conference of Organization Innovation (ICOI), 2-4 July, Huahin, Thailand.

Von Schlippe, A., \& Frank, H. (2013). The theory of social systems as a framework for understanding family businesses. Family Relations, 62(3), 384-398. 
Stubner, S., Blarr, W. H., Brands, C., \& Wulf, T. (2012). Organizational ambidexterity and family firm performance. Journal of Small Business \& Entrepreneurship, 25(2), 217-229.

Tàpies, J., \& Fernández Moya, M. (2012). Values and longevity in family business: Evidence from a cross-cultural analysis. Journal of Family Business Management, 2(2), 130-146.

Tirdasari, N. L., \& Dhewanto, W. (2012). Family business succession in Indonesia: A study of hospitality industry. Procedia-Social and Behavioral Sciences, 57, 69-74.

Vallejo, M. C. (2011). A model to study the organizational culture of the family firm. Small Business Economics, 36(1), 47-64.

Whatley, L. (2011). A New Model for Family Owned Business Succession. Organization Development Journal, 29(4), 21-32.

Zachary, R. K. (2011). The importance of the family system in family business. Journal of Family Business Management, 1(1), 26-36.

Zellweger, T. M., Nason, R. S., \& Nordqvist, M. (2012). From longevity of firms to transgenerational entrepreneurship of families: Introducing family entrepreneurial orientation. Family Business Review, 25(2), 136-155. 
